\title{
Family Planning in Africa: Old Belief and New Perspective
}

Yanyi K. Djamba

\begin{abstract}
This article reviews the underlying assumption of most family planning programmes in Africa. The results show that the hypothesis that African men oppose the use of contraceptive methods is erroneous. Rather, current data reveal that men want to learn more about birth control. Also, most men and women believe that husbands are the primary decision-makers of reproductive and sexual lives. A new perspective for men's involvement programmes is then provided as a route to low fertility in Africa.
\end{abstract}

\section{Résumé}

Le présent article passe en revue l'hypothèse de base de la plupart des programmes de planification familiale en Afrique. Les résultats montrent que l'hypothèse que les hommes en Afrique s'opposent à l'utilisation des méthodes contraceptives modernes est erronée. Tout au contraire, les données actuelles révèlent que les hommes veulent en savoir davantage sur le contrôle des naissances. Aussi, la plupart des hommes et des femmes pensent-ils que les maris (époux) sont les premiers à prendre des décisions en ce qui concerne la vie reproductive et sexuelle. Une nouvelle approche consistant à mettre en oeuvre des programmes visant à impliquer les hommes semble constituer la voie royale vers une baisse de la fécondité en Afrique.

\section{INTRODUCTION}

Family planning programmes in Africa have traditionally concentrated on reaching women through the maternal and child health services. Based on the conventional wisdom that African men oppose family planning, this female-dominated structure of most family planning programmes neglects men who in many African countries usually make decisions in matters of sex and family size. The purpose of this article is to show that this view which has reinforced the belief that family planning is women's business is wrong, and that early programmes of family planning missed a key ingredient for success: men.

Though some men may be reluctant to practice birth control themselves, recent survey data show that men are more conscientious users than are women when they do accept family planning (Stokes, 1980). Men are also more likely than women to persuade their friends to accept family planning. And when male family planning acceptors select female methods, they are, compared to women, more often able to get their partners to use them successfully (Brown et al. 1990). As efforts to bring family planning to women are almost exhausted, now is the time to include men in family planning campaigns.

After reviewing data from different surveys, policy recommendations are presented for increasing contraceptive use through men's involvement. The ultimate aim is to reach a situation where it will no longer be necessary to develop separate programs for men and for women, but programmes for couples in the interest of the family as a social unit.

\section{Do African Men Really Oppose Family Planning?}

Survey findings do not support the assumption that African men are opposed to family planning or that they have little interest in spacing and limiting births. On the contrary, there is evidence that men are aware of family planning and are open to learning more about it. In a Zimbabwean national survey of men with reproductive-age wives, Adamchak and Mbizvo (1991) found that virtually all men had received family planning information mainly from radio and personal communications. Interestingly, nearly 85 percent of these Zimbabwean men said that they would like to learn more about family planning. 
A 1989 survey of married men in two suburbs of Accra revealed that men expressed interest in using family planning services, both for themselves and their wives (Armstrong and Onsei, 1989). Similarly, data from a 1982 survey of male Khartoum residents show that three in five men with reproductiveage wives wanted to use family planning, and more than half of the men wanted to learn more about male and female sterilization (Mustafa and Mumford, 1984).

Cases in which husbands oppose the use of family planning are usually negligible. A study conducted in Dakar, for example, shows that only about six percent of teachers oppose the use of family planning. This value represents the highest rate across all employment categories; moreover, it does not appear surprisingly high given the fact that teachers want relatively more children than do other workers (Posner and Mbodji, 1989).

Table 1 shows national percentages of currently married women who are not using a contraceptive method because of opposition from their husbands. These data show that husband's opposition is not the most important reason for nonuse of contraceptive methods. In fact, a majority of women who reported their husbands as disapproving have never discussed family planning with them. Thus, the perception of husband's opposition is associated with the lack of communication: "ignorant of their spouses' views, women assume them to be negative [...]" (Bongaarts and Bruce, 1994:23). In Kenya, for example, the lack of communication between spouses proved to be a more common obstacle to contraceptive use than male opposition (MacCauley et al. 1994:18).

\section{Who is the Decision-Maker?}

Conjugal relationships are largely defined in cultural terms. The relative power of spouses in the making of fertility decisions involves their socialization to specific roles and their interaction over the reproductive life span. Although these relationships may vary from one culture or ethnic group to another, there is evidence that many African men and women believe that husbands should be the primary decision-makers regarding contraceptive use and marital sexual activity.

Data from a 1991 survey of five urban areas in Nigeria illustrate this pattern. To discover which spouse is the most influential in family decisions, the following question was asked to both husbands and wives: "In family decisions, are you influenced more by your own views, the views of your spouse, or those of your parents, relatives, and friends?" As shown in Table 2, about 88 percent of married men and 78 of married women replied that husbands' views are more influential in family decisions (Isiugo-Abanihe, 1994). Only seven percent of husbands and 16 percent of wives said women are more influential.

Examining both quantitative and qualitative data from Ghana, Ezeh (1993) found that spousal influence regarding reproductive goals is an exclusive right exercised only by the husband. A woman's characteristics do not affect her husband's family planning attitude, but her contraceptive attitude largely depends on her husband's characteristics. The author argues that this pattern operates both through men's comparative advantage in mate selection and through cultural norms which subjugate women to men. Further evidence of husband's role in family decision matters is given in Table 3. Data in this table reveal that a large majority of men and women agree that most often husbands make reproductive decisions, decide whether or not to have sexual relations, decide upon the duration of abstinence, and make choices about the practice of family planning.

In a 1991 survey conducted in Kinshasa, Zaire, married men and married women were asked to name the person who decided that contraceptives be used in their marriages (Djamba, 1994). Results in Table 4 show that among users of modern methods of birth control, 67 percent of men and 65 percent of women said the decision was made by the husbands. For all (modern and non-modern) methods, the figures are 64 and 57 per cent, respectively for male and female respondents.

These men and women were also asked to report on their sources of contraceptive information, especially the first and last methods that they have ever used. Table 5 shows that 18 percent of women received information on the first contraceptive method from their husbands; the figure goes up to 25 percent for the most recent contraceptive method used. In contrast, for both the first and last methods ever used, only 5 percent of men said they got contraceptive information from their wives. 
These results support the idea that men are in charge of family decisions, and that they constitute an important source of contraceptive information for their wives.

\section{What Happens When Men are Involved in Family Planning?}

During the past decades, the need for family planning - well known as unmet need - has been rationalized by the proportions of sexually active women who do not wish to become pregnant but do not practice birth control. Such a measure may not reflect reality because most reproductive decisions are not made by women but by men. Several countries in Sub-Saharan Africa have conducted experimental programs to provide family planning information, services, and supplies to men. But only programs that also focus on enhancing couple communication about reproductive behaviour have produced positive results.

Communication between spouses is positively associated with contraceptive use, duration and effectiveness of use, and negatively associated with demand for children and fertility preferences. Furthermore, communication is assumed to lead to greater empathy and to increase a couple's ability to act together to achieve goals. However, because of the sensitivity of the topic, feelings of shyness or modesty, and fear of challenging the husband's authority, women are less likely to initiate discussions about family planning and sexual activity. Nonetheless, most women are willing to talk about reproductive matters if the topics are initiated by their husbands.

The Ghanaian approach is very interesting. Ghanaian family planning professionals sponsored tournaments of games that men like, such as soccer and checkers, to get men and women talking about family planning. They recruited wives to oppose their husbands, altering the rules where necessary to make a fair match. In these games, male players are only allowed to use their left feet, and the female players are allowed extra members. The winners are given a gallon of condoms, or another prize that will spark conversation about family planning. Couples are talking, and family planning is losing its wrong connotations. Half of the reduction in fertility in one rural area in Ghana is associated with the acceptance of family planning by men.

Another relevant experiment was conducted in Addis Ababa, Ethiopia (Terefe and Larson, 1993). Married couples were randomly selected and further divided in two groups. In the control group, wives were given a health talk on their own during the family planning home visitation education. Husbands were included in the experimental group. A greater proportion of couples in the experimental group were practising modern contraception following the home visitation. The inclusion of husbands nearly doubled the prevalence of modern contraception (Terefe and Larson, 1993).

Data in Table 6 clearly show that engaging men's interest and support can considerably increase contraceptive use. On average, the (perception of) husband disapproval led to a reduction in use by two-thirds. Furthermore, women who approved of family planning were more likely to use a modern method if they had discussed with their husbands in the year before the interview than were women who approved of family planning but had not discussed it (MacCauley et al. 1994:25).

The most consistent finding from the preceding analysis is that husbands and wives frequently do not discuss contraception. As a result, women think their husbands do not approve of family planning. But in the cases where husbands are asked, these men claimed to approve of birth control, although they do not usually talk about the subject with their wives (Chibalonza et al. 1989; Fakeye and Babaniyi, 1989). As van de Walle and Traore (1986) noted, men and women live in two different worlds in respect of family planning. This social boundary must be broken for effective practice of family planning in marriage.

\section{How to Include Men?}

Generalizations that emerge from recent research and field observations are that most men are not against family planning and that they want to learn more about it, preferably from male workers. Yet, up to now, most family planning providers are women, or men trained to deliver services to women. Consequently, they are uncomfortable talking to male clients about sexuality, genitals, erections, wearing condoms, ejaculation, pre-ejaculate fluid, abstinence, multiple partners, and all other issues 
that should be involved in counselling men in modern or traditional family planning. Though, these sensitive subjects are themes that husbands and wives need to be able to talk to each other about if they are going to use contraception effectively.

These observations call for programs that reach out men and enhance men's cooperation in the area of reproductive health. Such programs should focus on:

- training of male family planning workers to provide appropriate information to men;

- $\quad$ persuading men to accept and use male methods, and to be supportive of their partners' effective use of family planning; and,

- promoting greater spousal communication regarding family planning, as a means to ensure better sexual life and reproductive health that benefit all the family.

These programs should be designed to promote male involvement and shared responsibility for reproductive health, not male dominance (Piotrow et al. 1992). Family planning managers should know that discussions over contraceptive and sexual matters may not be considered respectable subjects in some social settings. Therefore, asking simple questions such as: "Would you be comfortable discussing this with your partner?" "Would you like your partner involved?" helps avoid unintended conjugal conflicts. Where feasible, special sessions can be designed for couples (Bongaarts and Bruce, 1994:42).

Getting sexual partners to talk to one another about family planning is evidently an important step towards eventual adoption and sustained use of birth control (DHS, 1988). However, communication campaigns and counselling are most likely to be effective when they recognize existing cultural patterns of decision-making. Informing men, and preparing them to be supportive of women's family planning needs and practices, is probably the shortest route to low fertility in Africa.

\section{$\underline{\text { Notes }}$}

${ }^{1}$ This article is based on a paper presented at the 1994-95 workshop of Options Fellows Program in Population Policy Communications, the Population Reference Bureau, Inc.

${ }^{2}$ The author is grateful to James Opare, Kelly James, and an anonymous reviewer for their helpful comments on earlier versions of this paper. 
Table 1.Percentage of women who do not use contraception because their husbands oppose, among all non-users

\begin{tabular}{||l||c||c||}
\hline Country & Year of survey & $\begin{array}{c}\text { \% of non-users } \\
\text { due to husbands' } \\
\text { opposition }\end{array}$ \\
\hline \hline Cameroon & 1991 & 1.1 \\
Malawi & 1992 & 2.7 \\
Namibia & 1992 & 1.4 \\
Tanzer & 1992 & 2.5 \\
Zambia & $1991 / 92$ & 3.1 \\
Burundi & 1992 & 3.7 \\
Ghana & 1987 & 5.7 \\
Kenya & $1988 / 89$ & 6.8 \\
Mali & 1987 & 19.8 \\
Uganda & $1988 / 89$ & 12.1 \\
\hline
\end{tabular}

Sources:Demographic and Health Surveys: for Cameroon, Studies in Family Planning 1993, 24 (2):134; from Malawi to Zambia, Tables 4.11 of DHS country reports; from Burundi to Uganda, adapted from Bongaarts and Bruce (1994:10).

Table 2.Percentage distribution of respondents regarding family decision-making, Nigeria, 1991

\begin{tabular}{|c|c|c|c|c|}
\hline \multirow{2}{*}{$\begin{array}{l}\text { Who influences } \\
\text { family decisions } \\
\text { most? }\end{array}$} & \multicolumn{2}{|c|}{$\begin{array}{l}\text { Husbands' } \\
\text { responses }\end{array}$} & \multicolumn{2}{|c|}{ Wives' responses } \\
\hline & Percent & $\mathrm{N}$ & Percent & $\mathrm{N}$ \\
\hline Husband & 87.7 & 1,694 & 77.6 & 2,385 \\
\hline Wife & 6.7 & 206 & 16.0 & 492 \\
\hline Kin/friends & 1.4 & 42 & 1.9 & 58 \\
\hline Others & 2.0 & 61 & 1.3 & 40 \\
\hline No response & 2.2 & 70 & 3.2 & 98 \\
\hline Total & 100.0 & 3,073 & 100.0 & 3,073 \\
\hline
\end{tabular}


Source: Isiugo-Abanihe (1994:153).

Table 3.Percentage distribution of responses to statements about reproductive decisionmaking, by sex of respondent, Nigeria, 1991

\begin{tabular}{|c|c|c|c|}
\hline \multirow{3}{*}{ Statement } & \multicolumn{3}{|c|}{ Response } \\
\hline & \multicolumn{3}{|c|}{ No option } \\
\hline & Agree & Disagree & $\begin{array}{l}\text { or } \\
\text { response }\end{array}$ \\
\hline Men decide family size & & & \\
\hline Male & 56.7 & 25.3 & 18.0 \\
\hline Female & 47.6 & 32.3 & 20.1 \\
\hline Men decide when to have sex & & & \\
\hline Male & 59.9 & 26.2 & 13.9 \\
\hline Female & 43.8 & 36.4 & 19.8 \\
\hline $\begin{array}{l}\text { Men decide duration of } \\
\text { abstinence }\end{array}$ & & & \\
\hline Male & 57.1 & 24.6 & 18.3 \\
\hline Female & 42.6 & 35.1 & 22.3 \\
\hline $\begin{array}{l}\text { Men decide whether to practice } \\
\text { family planning }\end{array}$ & 48.0 & 33.7 & 18.3 \\
\hline Male & 46.1 & 34.9 & 19.0 \\
\hline Female & & & \\
\hline
\end{tabular}

ource: Isiugo-Abanihe (1994:154). 
Table 4.Percentage distribution of user couples by initiator of family planning, Kinshasa, Zaire, 1991

\begin{tabular}{|c|c|c|c|c|}
\hline \multirow{2}{*}{$\begin{array}{l}\text { Who decided } \\
\text { that family } \\
\text { planning be } \\
\text { used? }\end{array}$} & \multicolumn{2}{|c|}{$\begin{array}{l}\text { Husbands' } \\
\text { responses }\end{array}$} & \multicolumn{2}{|c|}{ Wives' responses } \\
\hline & Modern & Any & Modern & Any \\
\hline Husband & 67 & 64 & 65 & 57 \\
\hline Wife & 28 & 29 & 31 & 35 \\
\hline Other & 5 & 7 & 4 & 8 \\
\hline Total & 100 & 100 & 100 & 100 \\
\hline
\end{tabular}

Source: Djamba (1994:34).

Table 5.Sources of contraceptive information: first and last methods ever used, Kinshasa, Zaire, 1991

\begin{tabular}{|c|c|c|c|c|}
\hline \multirow[t]{2}{*}{ Source } & \multicolumn{2}{|c|}{$\begin{array}{l}\text { Husbands' } \\
\text { responses }\end{array}$} & \multicolumn{2}{|c|}{ Wives' responses } \\
\hline & $\begin{array}{l}\text { First } \\
\text { method }\end{array}$ & $\begin{array}{l}\text { Last } \\
\text { method }\end{array}$ & $\begin{array}{l}\text { First } \\
\text { method }\end{array}$ & $\begin{array}{l}\text { Last } \\
\text { method }\end{array}$ \\
\hline School & 37 & 23 & 24 & 13 \\
\hline Health staff & 7 & 13 & 16 & 23 \\
\hline Parents & 3 & 1 & 3 & 3 \\
\hline $\begin{array}{l}\text { Other family } \\
\text { members }\end{array}$ & 8 & 6 & 6 & 4 \\
\hline Spouse & 5 & 5 & 18 & 25 \\
\hline Friends & 28 & 29 & 27 & 25 \\
\hline Media & 8 & 16 & 4 & 6 \\
\hline Other sources & 4 & 6 & 2 & 2 \\
\hline Total & 100 & 100 & 100 & 100 \\
\hline
\end{tabular}

Source: Djamba (1994:17). 
Table 6.Percentage of contraceptive use among married women by husband's approval/disapproval of family planning

\begin{tabular}{||l||l||r||r||}
\hline \multicolumn{1}{|c|}{ Country } & $\begin{array}{c}\text { Year of } \\
\text { survey }\end{array}$ & $\begin{array}{c}\text { Husband } \\
\text { approves }\end{array}$ & $\begin{array}{c}\text { Husband } \\
\text { disapproves }\end{array}$ \\
\hline \hline Burundi & 1987 & 14 & 3 \\
Kenana & 1988 & 18 & 6 \\
Mali & $1988 / 89$ & 36 & 16 \\
Uganda & 1987 & - & - \\
\hline
\end{tabular}

Source:Adapted from Bongaarts and Bruce (1994:26). Estimates derive from logistic regression models with controls for age, education, residence, and desire for more children.

$(-)$ indicates no significant effect.

\section{REFERENCES}

- Adamchak, Donald J., and Michael T. Mbizvo. 1991. "Family planning information sources and media exposure among Zimbabwean men."Studies in Family Planning 22 (5):326-331.

- Armstrong, Gregory L., and Lawrence Onsei. 1989. Male Attitudes Towards Family Planning in Accra, Ghana. Ghana: Department of Medicine, University of Ghana Medical School.

- Bongaarts, John, and Judith Bruce. 1994. "The causes of unmet need for contraception and the social content of services." Research Division, Working Paper No. 69. New York: The Population Council.

- Brown, J.E., F.M. Coeytaux, P. Hirstio-Snellman, S. Khasiani, and R. Oniang'o. 1990. "Listening to the clients: Qualitative family planning studies from Kenya and Zambia." Final Report submitted to FINNIDA. New York: The Population Council.

- Chibalonza, Kashwantale, Chirwisa Chirhamoleka, and Jane T. Bertrand. 1989. "Attitudes toward tubal ligation among acceptors, potential candidates and husbands in Zaire." Studies in Family Planning 20 (5):278.

- $\quad$ DHS, 1988. Family and Health Survey II. Columbia, MD: Institute for Resource Development.

- Djamba, Yanyi K. 1994. Spouses' Differential Roles in Control of Fertility: Evidence from Kinshasa. Study Report prepared for the World Health Organization. Kinshasa, Zaire: Department of Demography, University of Kinshasa.

- Ezeh, Alex Chika. 1993. "The influence of spouses over each other's contraceptive attitudes in Ghana." Studies in Family Planning 24 (3):163-174.

- Fakeye, O., and O. Babaniyi. 1989. "Reason for non-use of family planning methods at llorin, Nigeria: Male opposition and fear of methods." Tropical Doctor 19:114.

- Isiugo-Abanihe, Uche C. 1994. "Reproductive motivation and family size preferences among Nigerian men." Studies in Family Planning 25 (3):149-161.

- MacCauley, Ann P., Bryant Robey, Ann K. Blanc, and Judith S. Geller. 1994. "Opportunities for women through reproductive choice." Population Reports, Series M, No. 12. Baltimore: Johns Hopkins School of Public Health, Population Information Program.

- Mustafa, Mutasim A. B., and Stephen D. Mumford. 1984. "Male attitudes towards family planning in Khartoum, Sudan." Journal of Biosocial Science 16:437-449.

- Piotrow, Phyllis T. et al. 1992. "Changing men's attitudes and behavior: The Zimbabwe male motivation project." Studies in Family Planning 23:365-375.

- Posner, Jill K., and Fara Mbodji. 1989. "Men's attitudes about family planning in Dakar, Senegal." Journal of Biosocial Science 21:179-291.

- Stokes, Bruce. 1980. "Men and family planning." Worldwatch Paper, No. 41. Washington DC: Worldwatch Institute. 
- Terefe, Almaz, and Charles P. Larson. 1993. "Modern contraceptive use in Ethiopia: Does involving husbands make a difference?" American Journal of Public Health 83:1567-1570.

- $\quad$ van de Walle, Francine, and Baba Traore. 1986. Attitudes of Women and Men Toward Contraception in a Town in Burkina Faso. Fertility Determinants Research Notes, No. 14, New York: The Population Council. 